\title{
Modelo de ciclo de negocios real con dinero endógeno y política monetaria pasiva
}

Real business cycle model with endogenous money and passive monetary policy

\author{
Carlos Guberman \\ Facultad de Ciencias Económicas- \\ Universidad Argentina de la Empresa, \\ Argentina \\ E-mail:cguberman@uade.edu.ar
}

\author{
David Ezequiel Cymbler \\ Facultad de Ciencias Económicas- \\ Universidad Argentina de la Empresa, \\ Argentina \\ E-mail:dcymbler@uade.edu.ar
}

Fecha de recepción: 14/10/2014 Fecha de aprobación: 11/02/2015

Palabras clave

- Dinero

- Política monetaria

- Ciclos reales

- Mercados financieros

- Banca central

\section{Resumen}

Construimos un modelo de ciclo de negocios real con dinero endógeno y política monetaria pasiva, que muestra algunas particularidades en cuanto a la dinámica de las tasas de interés y los mercados de crédito. Encontramos que el modelo es estable, aspecto que consideramos ausente en la literatura relacionada con la política monetaria pasiva. Creemos que este trabajo puede ser un buen punto de partida para el análisis de lo sucedido antes, durante y después de la crisis financiera internacional que comenzó en el mercado de crédito colateralizado.

Keywords

- Money

- Monetary policy

- Business cycle

- Financial markets

- Central banking
Abstract

We built a real business cycle model with inside money and passive monetary policy that shows some interesting features regarding interest rate dynamics and credit market behavior. We find that the model is stable, a feature that was difficult to find in the literature on passive money. We think this would be a good starting point to analyze monetary policy before and after the international financial crisis that started at the market for secured loans. 